\title{
A GYÖRI ELIT ÉRTÉKRENDSZERE ÉS MAGATARTÁSA AZ 1870 ÉS 1945 KÖZÖTTI GAZDASÁGI ÉS POLITIKAI VÁLSÁGOK IDEJÉN
}

\author{
(The Scale of Value and Behaviur of the Elite in Györ during \\ the Economic and Political Crisis between 1870 and 1945)
}

\section{SZAKÁL GYULA}

Kulcsszavak:

györi elit gazdasági és politikai válság megoldási módok emberi értékek

Minden közösséget jellemez, hogy milyen elitet képes létrehozni. Az elitek kialakulása, szerkezete, a benne megjelenö teljesítmények és szerepkörök erösen uúfüggöek. A györi elit két világháború közötti szereplése szépen bizonyítja ezt a megállapitást. A város sorsának alakulását a kedvezö földrajzi elhelyezkedését nem lebecsülve, sokkal nagyobb mértékben a település gazdasági, politikai és nem utolsósorban kulturális elitje határozta meg. A II. világháborúig ez a három elitcsoport egymással való viszonyát tekintve sokkal koharensebb volt, mint napjainkban. Györ befogadó jellege, az urbánus életmód és értékrendszer, a lehetöségek megragadásának képessége, a realitás- és a szociális érzék, a személyes felelösség- és szolidaritás tudat, a nagyobb idötávlatok iránti érzékenység meghatározó volt mind a gazdasági, mind pedig a politikai krizishelyzetekben. Mivel a városi elit a 19. század elejétöl a II. világháborúig lényegében ugyanazon kapcsolathálóból állt, erös családi stabilitással a válaszreakciók is hasonloak voltak. A kereskedőváros kríiséböl a korszerü iparvárossá váltást, a helyi közösségi sikert ugyanaz az elit vitte véghez, aki szembe találta magát a II. világháborút megelözö, majd a háborús évek megpróbáltatásaival. Több emberöltö alatt a városi gazdasági és politikai vezetö réteg befogadó mentalitása révén nagyon jól integrálta az erre amúgy is fogékony és hajlandó zsidó polgárokat. A vészkorszak éveiben a város keresztény politikai elitje mindent megtett, hogy sorsukat megkönnyítse.

Minden kisebb-nagyobb közösséget jellemez és egyben minősít, hogy milyen elitet képes létrehozni, kihordani magából. Ez igaz egy nemzetre, azon belül a kisebbségekre és a településekre egyaránt. Az elitek kialakulása, annak szerkezete, a benne megjelenő szerepkörök rendkívül erősen ,útfüggőo". Ez utóbbi kifejezés alatt két tényező értendő. Egyrészt a helyi elit kialakulásának és formálódásának az útja és módja már eleve komoly nyomokat hagy a vezető réteg tagjainak az értékrendszerén, mentalitásán. A másik pedig az időtényezö. Mi az az időhorizont, ami rendelkezésre áll, hogy az értékek megszilárduljanak, és a hatékony magatartásformák generációkon keresztül a családban, a civil szerveződések, tehát a társas együttlét különböző szinterein áthagyományozódhatnak a fiatal generációra? Szakmám egyik jeles képviselóje, Reinhard Koselleck „Vergangene Zukunft” müvében írja amelynek egyébként semmi köze az elithez, de gondolatai bámulatosan jól átvihetők egy másik gondolkodási térre -, hogy a tapasztalás tere (Erfahraungsraum) és az új várakozási horizont tere (Erwartungshorizont) szépen bizonyítja a két pólus közé szervezödő magatartásminták és a közöttük keletkező feszültségek küzdelmét 
(Koselleck 1979, 112). Egy egészen más témában és összefüggésben írja Jan Assmann a kulturális emlékezetről: „Hogy az ember viszonyba léphessen a Múlttal, az utóbbinak ilyenként kell tudatosulnia... Elöször is a Múlt nem tünhet el nyomtalanul, léteznie kell rá vonatkozó bizonyítékoknak. Másrészt, a bizonyítékoknak jellegzetes különbséget kell felmutatnunk a Mához képest." (Assmann 1999, 32)

\section{A győri elit reagálása a gazdasági válságra}

Györ - mondhatnánk - szerencsés város. A szerencse azonban sohasem véletlen, azaz a véletlen mindig a szüksségszerüségek találkozásainál keletkezik. Ez a szükségszerüség pedig az 1800-as évek közepétöl Györt a korabeli gazdasági térben földrajzilag igen kedvező helyzetben találta. A Dél-Alföld és a Bácska-Bánát gabonáját ugyanis városunkon keresztül továbbították Bécs piacára. Ezt a lehetőséget azonban ügyesen kellett kihasználni. Akkor ez sikerültt ${ }^{1}$.

A győri vizekre érkezö al-dunai hajók és dereglyék, a Rába és a Duna-parton sorakozó raktárak, vagy aratás után a város utcáin óriási rakásokban álló gabona uralta a település arculatát és hangulatát. Telente nemritkán másfélszáz hajó pihent a kikötőkben, melyek egyharmada helyi polgárok tulajdonában volt. A folyópartokon és a mai Árpád és Bajcsy-Zsilinszky út mentén sorakozó raktárak négymillió mérő gabona tárolására voltak alkalmasak. Ennek a hatalmas mennyiségú árunak a fogadása és továbbszállítása legalább háromezer embernek, a lakosság 15\%-ának adott biztos és tisztes megélhetést. A fellendülés tovagyürüző hatásai ennél szélesebbek voltak. A gazdagodó, nem ritkán hatalmas vagyonokat felhalmozó helyi kereskedők ugyanis a városban építkeztek. Az esetenként igen jelentős beruházások számos mesterembernek adtak munkát és biztosítottak ezzel családjuknak jövedelmet, akik viszont fogyasztásuk révén a kiskereskedők egyre gyarapodó üzleteinek vevőkörét növelték.

Mint már jeleztük, az építkezésekhez szükséges anyagi eröt a közvetító gabonakereskedők biztosították. A Délvidék és az Alföld terményeit Bécs felé szállították, az ehhez szükséges utat egészen a 19. század közepéig a Duna természetes medre nyújtotta. Kedvezö földrajzi helyzete révén Györ lett a találkozóhelye a magyar eladóknak és a nyugatról érkezö vevöknek, akik egyre nagyobb tételben vásároltak búzát, rozst, később árpát és kukoricát. Természetesen a Duna-parti városok, így Moson, de különösképpen Komárom versengett Győrrel. Ez utóbbi sokáig igen kemény ellenfélnek bizonyult, és jelentősége abban az időben nagyobb volt, amire a komáromi belváros nagysága és épületeinek tekintélyes volta is enged következtetni.

Az osztrák-magyar vasúttársaság azonban 1854 és 1856 között Györig építette ki a bécsi vasutat, ami által a város szerepe rendkívüli módon megnőtt. Mivel a mosoni Duna-ág eliszaposodásával az egyik vetélytárs kiesett, Győr maradt az egyetlen központ, ahonnét az uszályokkal és dereglyékkel igencsak lassan és körülményesen szállított gabonát vasúton lehetett Bécs, majd később SopronEbenfurt, végül Szombathely-Graz felé szállítani. Ennek köszönhetően az 1850-es 
évektől kezdve a kereskedelmi fellendülés annyira látványos volt az idegenek szemében, hogy az ebben az időben keletkezett „kalmár város” elnevezés még napjainkban is él a városi polgárok tudatában. A bácskai és bánáti nagybirtokosok és hajósgazdák, valamint az osztrák molnárok, sőt a távolabbi vidékek gabonakereskedői egyre sürủbben találkoztak Győrben. A máig híres, délvidéki földbirtokos Lelbach, Fernbach dinasztiák szinte kizárólag Györben értékesítették terményeiket. A tranzakciók lebonyolítását természetesen a helyi kereskedők végezték. Ebben a nyugodt békevilágban rengeteg tőke, szaktudás és tapasztalat halmozódott fel. A fỏvárosban is hírnévre szert tett Strasser és König, a Schreiber D. és fiai, valamint a Fleisch Samu vállalkozás Györben kezdte meg üzleti tevékenységét. De itt alapozták meg a sikerüket és váltak tekintélyes városi polgárokká, lokálpatriótává a Fleischman család tagjai, melynek egyik ága Svájc legnagyobb, de még európai viszonylatban is az egyik legtekintélyesebb családja.

A fellendülésnek ez a második szakasza azonban alig egy évtizedig tartott. Az 1860-as évek elején megépült Buda-Trieszt vasút a föváros szerepét teljesen felértékelte. Az agrártérségek gabonáit így már csak Pest-Budáig kellett vízi úton szállítani, majd innét vasúton továbbították. Ez a változás alapjaiban rendítette meg a győri gabonakereskedelmet. Fénykorában közel 600 család foglalkozott városunkban gabonakereskedelemmel és fuvarozással. Közülük 80-90 család kifejezetten gazdagnak számított. A korábbi lehetőségek gyors megszünése valóságos pánik hangulatot idézett elö.

A helyi sajtó és a közvélemény valóságos katasztrófáról beszélt. A legtöbb nagykereskedő Pestre, Nagykanizsára vagy Bécsbe tette át székhelyét, és ezáltal létszámuk 1881-re mindössze 17-re csökkent az öt évvel korábbi 84-gyel szemben.

A válság azonban korántsem volt olyan mély és megrendítö, mint gondolnánk. A város gazdasági vezető rétege, a korszak sikeremberei megkísérelték a védekezést. Már a válság első jeleire megkezdödött azoknak a stratégiáknak a kidolgozása, amelyek a kedvezötlen gazdasági helyzetet voltak hivatva elhárítani. Az előnyös földrajzi fekvés önmagában még nem elegendő a stabil növekedés biztosításához. A technikai fejlődés, ebben az esetben a vasút megjelenése, teljesen átrendezte e térség gazdasági elönyeit és hátrányait.

A városi kereskedők mindent megtettek, hogy elkeruiljék a teljes csődöt. Az első elképzelések és lépések azonban szinte kizárólag a régi gondolkodás továbbélését sejtetik. A gyors és kezdeti reflexként felmerült Györ-Pápa-Keszthely-Kanizsa vasút nem valósult meg, ezért tovább keresték a megoldást.

Felismerve a gőzhajózás előnyeit, 1865-ben maguk is kísérleteztek egy ilyen társaság felállításával. Pár évvel később már öt gőzösük vontatta az uszályokat. A forgalom csökkenését azonban nem tudták megállítani.

A túlélési stratégiák tárháza igen széles volt. Az állami segítség elnyerése reményében 1884-ben az akkor még kereskedelem- és iparügyi államtitkárt, Baross Gábort megválasztották Győr országgyủlési képviselőjének. A hagyományos szerepkört mindenáron megmenteni akaró szándék eredménye volt a közraktárak építése is. 
Szakál Gyula : A győri elit értékrendszere és magatartása az 1870 és 1945 közötti gazdasági és politikai válságok idején. - Tér és Társadalom 24. évf. 2010/2. 31-43. p.

Az első próbálkozások nem sikerültek, de a város még mindig elég erős volt ahhoz, hogy a pesti konkurencia komolyan aggódjon.

A klasszikus közvetítő kereskedelem fenntartása az állatforgalom területén sem bizonyult életképesnek, noha megpróbálkoztak vele. A győri kereskedők azonban gyorsan és hatékonyan tértek át az iparszerủ hizlalásra. A régióból (Bakony) és a tágabb térségböl (Alföld) beszerzett állatok stabil forgalmat jelentettek. A város fejlödését azonban a kereskedelem már nem tudta biztosítani. Azok az erőfeszítések azonban, amelyek erre irányultak, részben sikeresek voltak. Megakadályoztak egy látványos gazdasági összeomlást, a gazdasági elit elköltözését, vagy a város jelentéktelenségbe süllyedését.

Györ gazdasági életének minőségi változását a gyáripar megtelepítése hozta. Az előnyös földrajzi környezet (böséges ipari víz, Bécs és Budapest között többirányú vasúti kapcsolat) önmagában még nem bizonyult volna elegendỏnek. Kellett hozzá az a polgári mentalitás, amely felismerte az ipar hatását a város fejlődésére.

A gazdasági elit karrierútjait vizsgálva az egyik legfeltủnőbb sajátosság a város befogadó jellege volt. Itt csak összefoglalásként jeleznénk, hogy a Györbe került sikeres vállalkozók (Mayer, Halbritter, Csermák, Lelóczky, Réthy stb.) hihetetlenül gyorsan tudtak a régi, és talán patríciusnak mondható (Győr esetében ez nehezebben értelmezhetö, mint pl. a zártabb felvidéki városok esetében) családokkal házassági kapcsolatba lépni. Ez egyrészt igencsak komoly, sokszor számszerüsíthető anyagi elönyökkel is járt, ugyanakkor a kapcsolati tőkéhez való hozzájutás lehetőségét is biztosította számukra, ami legalább ilyen fontos volt. A házasságok kötését és a baráti kapcsolatok szerveződését nagyon megkönnyítette a vallási szerveződés. A zsidók és az evangélikusok esetében ez teljesen egyértelmủ volt. Egy-egy 3-4 ezer fös kisebbség egy katolikus püspöki székvárosban kapcsolataiban befelé fordul. A katolikus vallásúak esetében az egyház kifejezetten - és a korabeli társadalmi nyilvánosság szintjén is - törekedett a helyi társadalom szervezésére. Az újságok azonban arról tudósítottak, hogy a klérus igen elégedetlen volt a katolikus vallású képviselőkkel. Számtalanszor elmarasztalták ,„a jó katolikus családok vezető férfiúit”, hogy a liberális szabadkőmüves klikkel szavaznak. Élesen kikeltek a szabadkőműves páholy keresztény tagjai ellen. Egyébként a közgyűlés a páholy minden jelentösebb kezdeményezését nagy többséggel támogatta. A hagyatéki anyagból és a részvénytársasági jegyzőkönyvekböl az is kiderült, hogy több, igen tehetös (nem áttért) katolikus vállalkozó jó kapcsolatot tartott fenn zsidó pénzügyi és kereskedői csoportokkal. A katolikus sikeremberek is jól behatárolható területen éltek. Míg az előbb említett és kisebbségben lévő vallású polgárok lakóhelyi szegregációja a korábbi évszázad vallási türelmetlenségének volt köszönhető, addig a katolikusok esetében az anyagi lehetőségeik határozták meg a lakóhelyet. Ez Győr esetében egy T-alakot és hozzájuk tapadva kis fürtöket jelentett. Sikerült feltérképezni közel kétszáz vállalkozó lakását (illetve lakásait). A többségük a két föutcán (Baross u., Vilmos császár u.) és a hozzájuk közeli tereken és a csatlakozó utcák elején volt. Mintánkon belül még az is kimutatható volt, hogy az eliten belül az anyagilag kevéssé tehetös réteg fokozatosan távolodott ettől az egyébként rendkívül szűk belső tértől. A lakóhelyhez 
Szakál Gyula : A győri elit értékrendszere és magatartása az 1870 és 1945 közötti

gazdasági és politikai válságok idején. - Tér és Társadalom 24. évf. 2010/2. 31-43. p.

TÉT XXIV. évf. 2010 @ 2

A györi elit értékrendszere és ...

35

való kötődés hihetetlen erősségü. Interjúalanyaink még hatvan-hetven év elteltével is pontosan sorolták, hogy ki hol lakott.

A korabeli (19. század) befogadó jelleg, sőt szívó hatás után a másik jellegzetesség a hangsúlyozottan urbánus életmód és értékrendszer volt. Az 1800-as években még érezhető volt a földtulajdon jelenléte, noha szerepe egészen más volt, mint a többi vidéki nagyváros esetében. A jómódú kereskedők vásároltak ugyan a közeli dombokon szőlőbirtokot, vagy az alföldi részeken szántót, néha igen tekintélyes nagyságban, de ennek gazdasági súlya igazán nem volt. A pár holdas birtokoknak és a rajta lévő kúriának sokkal inkább reprezentatív szerepe volt, és a társas élet színtereként kezelték, nem gazdasági beruházásként. Egy korabeli napló és egy meghökkentően nagy helyismerettel rendelkező regényíró jóvoltából megtudtuk, hogy ezek az önmagukban ugyan egyáltalán nem kis értékủ birtokok és azok szép jövedelme a kereskedök vagyoni szerkezetében mégsem voltak számottevőek. Ezt támasztják alá Balázs Péter (1980) kutatásai, aki könyvében két kereskedỏ adófizetési kötelezettségét elemezve hasonló következtetésre jutott. A 20 és 30 holdnyi kert és szántó feltételezett bevételei alig maradtak el a kávés tevékenység hasznától. A kávékereskedések jövedelmei pedig messze eltörpültek a sertéskereskedelem bevételei mögött. Természetesen tudjuk, hogy a különféle jövedelmek eltérỏ kulcsokkal adóztak, de ezek valóban nem voltak nagy kiterjedésủ föld-darabok. A 20. század fordulójára azonban még ez a szolid földbirtokszerző magatartás is a minimálisra zsugorodott. Az 1900-as évek elején már valóban fehér hollónak számított a jelentős földekkel rendelkezö vállalkozó.

A hagyatéki leltárak helyrajzi adatai egyértelmüen bizonyították, hogy a nagyobb telkek (20-40 hold) birtoklása a legtöbb esetben jelentős telekspekulációs törekvést takart. Az 1929-33-as cím- és lakjegyzék alig több mint 30 birtokost jegyzett föl, többnyire 20-30 hold közötti földterülettel. Ök is inkább a város egyik falusias jellegü peremkerületéböl kerültek ki.

A gazdasági (kereskedelmi, ipari) elit körében a földszerzési törekvés a húszas évektől még inkább kuriózumnak számított. Ha találkoztunk is ilyennel, ez már egészen egyéni célokat takart. Mint pl. a dúsgazdag rỏfös Wolf testvérek az egyik fiúknak vettek egy több száz holdas , hobbi birtokot”. Ö azonban gyorsan megunta a gazdálkodást és visszatért a pénzügyi szférába.

Összefoglalóan elmondhatjuk, hogy a sikeres györi vállalkozókat a 19. század második felétöl már egyáltalán nem érdekelte a föld. (Egy-két kivétel természetesen akadt.) A győri földbirtokosok a megyéből kerülttek a városba, és a helyi társadalomhoz csak nagyon vékony szállal kapcsolódtak. Balázs Péter, aki a 19. század elejének és közepének legkiválóbb ismeröje, korában is hivatkozott munkájában meg sem említette a földtulajdont, helyette viszont a tökés vállalkozásoknak külön fejezetet szentelt (Balázs 1980). Elmondhatjuk, hogy a győri társadalom gyorsan levetkőzte a rendies sajátosságokat, de még a régi patrícius polgárok mentalitását is. A 19. század első felében habitusuk meghatározó vonása az erőteljes piacérzékenység volt. A Balázs Péter által idézett két kereskedỏ 4-5 különböző vállalkozásban (sertéskereskedelem, kávémérés stb.) vett részt. A feltünően innovatív gazdasági 
elit minden jövedelmezőnek tartott befektetést kipróbált. A korszakunkban érzékelt mentalitásjegyek minden elemét megtaláltuk már az 1800-as évek közepén. Érdemes kiemelni, hogy a kereskedelemhez kapcsolódó ipari vállalkozások már 1847-ben meglehetösen sok „kalmár” érdeklödését felkeltették. Egy gőzmalom igazgatóságában olyan polgárokat találtunk, akik három évtizeddel később, már igencsak idős korukban, a gyáripar első befektetői között voltak. Számomra igen tanulságos volt a kutatásaimat megelőző időszak forrásait olvasni. Kiderült ugyanis, hogy az új gazdasági ágakhoz való vonzódás, a beruházói kísérletezés igen sok esetben apáról fiúra szállt.

Talán arra sem haszontalan felfigyelni, hogy az 1850-70-es évek kalendáriumaiban milyen írások jelentek meg. Forrásaink töredékesek ugyan, és bizonyító erejüket sem szabad túlbecsülni, de mégis jelzik, hogy a város értelmiségének egy része milyen gondolatokra volt fogékony és milyen viselkedésmintát szerettek volna támogatni.

„Munka és tudomány” címmel 1857-ben, a szerző megjelölése nélkül, egy esszét közöltek a városi kalendáriumban, amelyben a munkát és a tudást (tanulást) népszerủsítették. A kis írás üzenete a tudás és a változtatási képesség összekapcsolása volt. Ha ,jobban és kényelmesebben akarnánk élni, mint éltek ős-apáink, ezt csak úgy eszközölhetjük, ha tudjuk, milyen mód által munkálkodhatunk kevesebb erövel és kevesebb időben legcélszerúbben" ( $A$ munka... 1857, 37). A szerző nem a városról, hanem a nemzetrỏl beszél, az üzenete mégis mintha a györieknek szólna. Figyelmeztetett arra, hogy nem lehet ma már „,egyszerüségben”, „elvonultságban” és „egyformaságban” élni. „Sőt, ha mi magyarok nem iparkodunk más nemzetek módjára elő̉rehaladni, nem csak nyomorgunk az életben, hanem akkor nemzetünk pusztulásnak is indul." A fejlődésnek a tudás és a munka az alapja, és boldogok azok az országok, ,hol a nép lelkesülve törekszik haladni”" (A munka... 1857, 37). Ez a reformkori, romantikus haladáseszme természetesen nem györi jelenség. A fogadtatása azonban mindenképpen figyelmet érdemel. A későbbiekben ugyanis a Györi Hírlap állandóan felszínen tartotta ezt a gondolatot, és a szabadkőmủves páholy még a liberális haladáseszme gyakorlati megvalósítása terén is szép sikereket könyvelhetett el.

Az igencsak hiányos források 1879-ben jeleztek egy hasonló szellemü írást. Stadler Károly körorvos Franklin Benjamin ismert munkája (,A szegény öreg Richard, vagy Eszköz a meggazdagodásban”) nyomán a helyes „polgári” magatartásról elmélkedett. Úgy vélte, mivel Magyarországon ,ipar hiányában az általános keresetek rosszak és napról napra változók", takarékosság nélkül nem képzelhetỏ el a polgári osztály gyarapodása (Stádel 1879,57). A takarékosság mellett a szorgalmat tartotta a másik polgári erénynek. A meggazdagodást nem tartotta erkölcstelennek, ha munkával történt. A szegénységet viszont sommásan bünnek tekintette, aminek oka az emberi lustaság.

A Györi Hírlap megjelenése (1886) és napilappá válása után ezek a gondolatok heti rendszerességgel helyet kaptak a lap hasábjain. A gyakran megismétlődő és legtöbbször naiv gondolatokból most csak azokat emeltük ki, amelyek a legtipikusabban fejezték ki a korabeli elit értékeit és mentalitását.

Munkakultuszukhoz, gyakorlatias szemléletükhöz köthetö még az akarat és a leleményesség tisztelete. Az akaratot a siker feltételének tartották, mely erőt ad a munkához. 
Szakál Gyula : A győri elit értékrendszere és magatartása az 1870 és 1945 közötti

gazdasági és politikai válságok idején. - Tér és Társadalom 24. évf. 2010/2. 31-43. p.

A polgári erényekhez tartozik a fáradhatatlanság és a szívósság. Legalább ilyen fontosnak tartották a leleményességet: azokat az ötleteket, amelyek hasznot hoztak. „Az élelmes vállalkozók üzletet csinálnak a szent természettel. Titkos barlangok torkában sört csapolnak, tengerszemeknél bográcsgulyás készül francia szakácskönyv után, lovagvárak színtereiben cipősuvickolók fogják el a turistákat, a kunyhóban nem szerelem, nem is a szegény juhászlegény, hanem 'Nanák'-at és 'Félszüzek'-et árulnak..." (Györi Hírlap 1896, 1)

Nagyon korán felismerték, hogy a város jövőjét csak a gyári jellegủ ipar megtelepedése biztosíthatja. Felismerték a váltás szükségességét, és megvolt az akarat, amivel a tudatos iparpártoló politikát megvalósították. A győri polgárban igen erőteljesen fogalmazódott meg saját fontosságának tudata. „Egy országot gazdaggá, naggyá és hatalmassá kereskedői és iparosai, tönkre pedig csak proletárjai tehetnek." (Neveljünk... 1896, 1-2) Meg kell jegyezni, hogy sem a sajtóban, sem pedig a közgyúlési jegyzőkönyvekben nem találkoztunk a gyáripar legcsekélyebb ellenzésével sem. A Dunántúli Hírlap felvállalta ugyan a romantikus antikapitalizmus egynémely értékét, de ez korántsem a győri polgárság véleménye volt.

Az önbizalom és az öntudat mögött a szorgalom és a szaktudás tisztelete áll. Szilárdan hitték, hogy kemény munkával és vasakarattal lehet csak eredményeket elérni. A polgári nyilvánosság színterei: a helyi sajtó, a kiadványok és a szakmai egyesületek fennmaradt jegyzőkönyvei a munka ma már szinte ismeretlen, kultikus felfogásáról tanúskodnak. „Aki sánta, dolgozzék a kezeivel - akinek nincs jobb keze, dolgozzék a ballal, segíteni csak azt kell, aki egyáltalán sehogy sem képes dolgozni." (A társadalom... 1896, 2)

Nagyon világosan érezték és érzékelték, hogy a város sorsa tỏlük függ. Az ő adójuk, iparkodásuk tesz egy települést sikeressé. „Csak a munka, az embert foglalkoztató, anyagot cserélö, forgalmat árasztó munka az, ami egy városnak jelent ad és jövőt biztosít." (Györ gyárváros 1896, 1)

A munkaszeretet mellett azonban kitapintható volt egy, már szinte a szüklátókörüség határát súroló prakticizmus. Mủveltségképükben szinte kizárólag csak a szakmai ismeretek domináltak. Az egyetemi tanulmányokat és így a diplomát, nem igazán becsülték. „Kínlódunk a jogi pályán, mert az illető úrfi, ki egy fejjel magasabbnak érzi magát a kereskedő, vagy iparos pályára menőtől - holott valódilag szánalmas pária, ki vaktában megy neki az életnek, eltölttve egész életét zárt levegőjü szobába, lassú előrehaladással, szánalmas kis fizetéssel. A jogi kurzuson mindenki feszít elkülönítve magát a kereskedö- és iparos pályára menőktől, kik eközben hatalmas vagyonra tesznek szert. [...] Legyünk végre mi is praktikus nemzet, $\mathrm{s}$ járjunk a biztos megélhetés útján, s ne a csillogó, de koldus pályához keressük a megélhetést." (Györi Hirlap 1896, 1)

A győri polgár perspektivikus gondolkodása azonban nem volt azonos a túlzott kockázatvállalási hajlammal. A gázgyár és a vízvezeték építésekor figyelték a többi város példáját, amelyek már megfizették a tanulópénzt. Az iskolák alapításakor is nagyobb önbizalommal vágtak bele olyan intézmények építésébe, amilyen már több müködött az országban. A város iparpártoló politikája az 1890-es években még úttörő cselekedet volt 
és végrehajtása komoly elszántságot igényelt. Az is érzékelhetỏ volt, hogy az esetenkénti kudarcok (amelyekböl volt azért böven), megérleltek egy óvatos magatartást.

A Monarchia győri polgárát a higgadt, de mégis karakteres liberális értékrend, a gyors alkalmazkodás, a jól informáltság és a nyugati életminták átvétele jellemezte. A húszas évektől azonban mindinkább elötérbe kerül a stabilitásra való törekvés és az óvatosság.

\section{A györi elit reagálása egy politikai, emberi válságra}

A gazdasági mentalitás fontos részét képezi az elönyszerzés, előnymegtartás és a hátrányelhárítás. Azt láthattuk, hogy az 1850-es évektől az 1890-es évek váltásáig minden magatartási jegy megjelent Győrben. Minek volt köszỏnhető ez a rugalmasság és a realitás érzék? Itt kell visszakanyarodnunk az útfüggőségre és az időtényezőre. Városukban - akárcsak az ország egészében - a helyi társadalom szerves fejlődését az 1848-49-es szabadságharctól a II. világháborúig, vagy annak előszeléig (itt a zsidótörvényeket értjük) a külsô politikai erőtér nem zavarta meg. A családon belül és a városi elit mikro- és makro szöveteiben két-három generációs tapasztalat és magatartásminta hagyományozódhatott át ${ }^{2}$.

Ennek a magatartásmintának a gyökerei pedig a város régebbi múltjába nyúlnak vissza. A katonaváros, püspöki székváros, patrícius jellegü polgárváros, nyitott kereskedőváros, majd iparváros változtatási igényében és küzdelmében az új elfogadása mindig győzött. A gazdasági és emberi kapcsolatok mindig nyitottak voltak. Ennek köszönhető a város befogadó jellege.

A győri elit magatartását a realitás- és szociális érzék, a szolidaritás és a személyes felelösségtudat jellemezte. Ezek a saját megállapítások sok hasonlóságot mutatnak Dolores L. Augustine és Pamela Pilbeam egész más időpontból levont megállapításaival, ahol a sikeres polgár magatartásjegyeinek tartják a barátság mintáit, a társadalmi kötelezettségek mértékét és a foglalkozási (professzionális) kapcsolatok milyenségét (Augustine 2001; Pilbeam 2001).

A gazdasági válságon és a sikeres modellváltáson túl a városi elitet - mind gazdasági, mind pedig politikai szereplöit - a II. világháború eseményei és a vele kapcsolatos zsidótörvények jelentősen érintették. Győr zsidó társadalma a 19. század közepétől igen gyorsan szervesült a város más vallású népességéhez. Ez a település zsidóságának elsöprő többségủ neológ vallásából, az ebből következő külső megjelenéséből és döntóen a mentalitásából következett. Ehhez természetesen partnerként kellett a keresztény gazdasági-politikai elit befogadó, lehetőségmegragadó szemlélete is. A helyi gazdasági életet modernizálni kívánó ipari részvénytársaságoknál, vagy akár a társadalmat jobbítani igyekvô szabadkómüves páholyoknál a város legkiválóbb polgárai felekezeti hovatartozás nélkül tudtak együttmúködni. Ennek egyik, ha nem döntő oka, hogy a vállalkozási konkurencia nem etnikumokhoz, hanem személyes teljesítményekhez kötődött. Ha az évente legsikeresebb vállalkozók vallási megosz- 
lását elemezzük, az derül ki, hogy Győrben éppen a zsidó származású sikerembereknek kellett keresztény társaik után kapaszkodni. A leggazdagabb vállalkozók körében kimutatható egy jelentős zsidó túlreprezentáltság, de ez nem volt magasabb, mint evangélikus vallású társaik körében ${ }^{3}$. Ha a látványos, mindenki által érzékelhető elemeket vizsgáljuk, úgy a Baross úti kereskedők, vendéglösök és háztulajdonosok körében jelenlétük inkább szolidnak tekinthető. A korábbi évtizedekben megalapozott befogadó jelleget nem tudta megbontani az ország más városaiban érzékelhető antiszemita ellentét. Bizonyosan ennek köszönhetö, hogy Pfeiffer Fülöp (1845-1930), a zsidó hitközség aktív szereplöje a város tiszti föorvosa lehetett. Ugyancsak itt kell megemlíteni az Auschwitzban tragikus sorsot ért Erdélyi Ernőt, aki ugyancsak közismert zsidó közéleti szereplése ellenére a városi tủzoltóságot megszervezte. A közismert nevek kiragadása mellett a hagyatéki leltárak áttekintéséből az is kiderült, hogy a keresztény közéletben pozíciót betöltő polgárok igen gyakran választottak zsidó származású háziorvost.

Egy társadalom - és ez a lokális közösségekre még inkább igaz - minősítöje az, miképpen bánik a betelepült idegenekkel, kisebbségi vallási, etnikai csoportjaival. Győr esetében a századfordulót követỏen a lakosság $10 \%$-a tartozott a zsidó vallásúak körébe. A gazdasági elit körében stabilan 30\% körüli pozíciót birtokoltak, míg a törvényhatósági bizottságban a képviselők 20-30\%-os arányát jelentették. Megkerülhetetlen szereplöi voltak tehát a város gazdasági és politikai életének. Ha a korabeli polgári társadalom kapcsolatrendszerét, érintkezési kultúráját vizsgáljuk, akkor nem találkoztunk olyan feszültséggel, melyet kifejezetten a zsidó és keresztény közösség ellentéte indukált volna. A gazdasági társaságok és a különböző civil szerveződések tagságát áttekintve nagyfokú együttmúködés mutatható ki. A legjobb példája ennek az 1901-ben alakult Philantrópia szabadkőműves páholy, amelynek a munkájába keresztény polgárok is bekapcsolódtak. A két vallási csoport közötti zavartalan kapcsolatra utal két visszaemlékezés (Quittner 1996; Körner 2005), amelyben nem említenek sérelmeket. Szólni kell viszont a Györi Püspökség által megjelentetett Dunántúli Hírlapról, amelyben rendszeresen jelentek meg óvatosabb, esetenként durvább, csipkelődő írások. Ezek hatása viszont elenyésző volt. A sikeres vállalkozók leszámozottai, a második generáció még képes volt emlékezni az 1910-es és az 1920-as évekre, de ők sem érzékeltek ilyen gondot.

Ezt a zavartalan kapcsolatot, a társadalmi események és kötelezettségek müködését jelzi egy ünnepségsorozat, amely az I. világháborúban elesett 85 győri, zsidó származású hősi halott nevét megörökítő márványtáblának a felavatását kísérte. 1923 őszét írtunk ekkor még. Az avató ünnepségen részt vett a Honvédelmi Minisztérium küldöttsége, a győri honvédezred díszszázada, a városi és megyei közigazgatás vezetői és a keresztény egyházak képviselöi ${ }^{4}$ (Lónyai 2004). A györi megyéspüspök, Fetser Antal maga is megható szavakkal emlékezett. A békesség hangja folytatódott és kiteljesedett az 1930-as évekre is. 1931 tavaszán a megyéspüspök beiktatásának negyed százados jubileumán dr. Schwarz Mór, Győr főrabbija feltűnő tisztelettel - nyilván szónoki fordulatoktól sem mentesen - méltatta a föpap tevé- 
kenységét. Szinte minden zsidó vallású győri emlékezett még arra, hogy az 1920-as évek kezdetén megjelenö antiszemita hullám a várost lényegében elkerülte.

Az együttélés és a segítő kapcsolat több színtéren működött. Míg a századforduló környékén az egykori dúsgazdag gabonakereskedỏ család egyik leszármazottja, Schreiber Ignác diákokat támogató alapítványt hozott létre, amely felekezeti hovatartozástól függetlenül segítette a rászorulókat, Back Hermann - noha a család már régen kikeresztelkedett - alapítványa kezdő vállalkozókat segített.

Az első világháborút követően is öt zsidó vallású győri polgárhoz köthető alapítvány létrehozása. Kohn Berta és testvére, Jenny a városi kórházat támogatta olyan jelentős összeggel, amit még Keresztes Fischer Ferenc belügyminiszter is méltatott. Buchwald Lajos és Schmiedl H. János gyárosok 1925 júniusában munkásokat segélyezö alapítványt jegyeztetett be. Nem csodálkozhatunk, ha a város mértékadó polgári elitje nem engedett a maga közelébe semmilyen antiszemita hangot. 1934 augusztusában dr. Szauter Ferenc polgármester méltatta dr. Schwarz Mór förabbi, közgyülési tag tevékenységét, amit a törvényhatósági bizottság határozatában rögzített.

Nem tekinthetjük véletlennek, hogy Győrben a liberális és szociáldemokrata pártok együttes támogatottsága a Horthy-rendszer átlagában messze meghaladta a konzervatívakét. Söt, amikor 1939-ben liberális pártok hiányában csak a Magyar Szociáldemokrata Párt létezett, a helyi választóktól százalékosan messze nagyobb támogatást kapott, mint Budapesten. Az elöbb leírt kapcsolatok tehát nemcsak a gazdag polgári elit prenditását tükrözik, hanem a györi lakosság széles rétegének az értékrendszereit is megjelenítik.

És mi történik azután? Míg korábban a gazdasági, most a nagypolitikai erỏtér rendeződött át. A II. zsidótörvény megszüntette a Győri Hírlapot, és 1939. október 1-jétỏl a Győri Nemzeti Hírlap megjelenésével a városi polgárok tájékoztatását teljesen a jobboldali, sőt a szélsőjobboldali médiumok vették át. A helyi polgárság körében, ugyancsak központi akaratra, már korábban megkíséreltek egy átrendezödést megindítani. Az 1919-ben létrehozott Baross Szövetség 1937 júliusában Györben is megalakult ${ }^{5}$. Első helyi, tétova lépései csak a fövárosi hírek és a központi magatartásminták (elvárások) közvetítésében merültek ki. A szövetség helyi tagnévsorának áttekintése arra enged következtetni, hogy a mértékadó városi polgárság kellő óvatossággal közeledett a szervezethez. Az elönyökkel való csábítás ellenére rengeteg apró-cseprő személyi üggyel voltak elfoglalva. A helyi nyilvánosság megszervezéséig ismertségük sem volt túl jelentős. Nem csak a mértékadó győri polgárság tartotta magát távol tỏlük, még a vezetöik sem örvendtek túl nagy presztízsnek. $\mathrm{Az}$ úgymond nemzeti keresztény iparosok és kereskedök tömörítését segítő szervezetnek elöbb egy ügyvéd, majd egy orvos lett a helyi vezetöje. Igaz, az utóbbi rendkívül ambiciózus volt, de rajta kívül kevesen dolgoztak.

A háborús eseményekkel egyidejüleg a helyi sajtóban állandósult az antiszemita formanyelv. Ez elég egyszerủen épült fel. Hol külföldi ügynököknek segítettek, hogy háborús győzelmi esélyeiket rontsák, más híradásokban fiatal keresztény lányokat kísérelnek megrontani, vagy éppen rémhíreket terjesztenek. A faktoidok tömkelegével bombázzák a győri polgárokat. 1944-től pedig a zsidók elleni intéz- 
Szakál Gyula : A győri elit értékrendszere és magatartása az 1870 és 1945 közötti

gazdasági és politikai válságok idején. - Tér és Társadalom 24. évf. 2010/2. 31-43. p.

TÉT XXIV. évf. 2010 『 2

A györi elit értékrendszere és ...

41

kedésekről tudósítanak rendszeresen. Természetesen nem maradhattak ki azok a hírek sem, amelyekben a zsidókat segító keresztény polgárokat ítélték el, kiemelve, hogy ezért milyen büntetést szabott ki rájuk a törvény.

Számunkra az a kérdés, miképpen reagált erre a győri lakosság. Az újság által lelkesen szított antiszemitizmus hatásával nem voltak megelégedve a szerkesztők, amit több esetben erös rosszallással közöltek is. Sôt, 1944. április 21-én a győri József Attila Kör 15-20 tagja tüntető sétát tartott a Baross úton, kabátjukban sárga szegfüvel. Hozzátehetjük, nem kis bátorság kellett ennek az egyszerü tettnek a végrehajtásához ezekben az időkben. Itt lényegében a kulturális elit egy megnyilvánulásával találkozhatunk. De legalább ennyire fontos számunkra, hogy mit csinált ezekben a hetekben a városvezető politikai elit. Legnehezebb próbatételnek a gettósításról szóló rendelet végrehajtása bizonyult. Nem szabad elfeledkezni arról, hogy olyan zsidó polgárokkal szemben is foganatosítani kellett a rendeletet, akik hoszszabb-rövidebb ideig a képviseló testület tagjai voltak, tehát munkatársi kapcsolatban álltak a polgármesterrel, illetve a rendelet kidolgozóival. Számuk nem volt kevés, hiszen az elmúlt bő 20 év során 50 és 100 között volt azok száma, akik virilisként vagy választóként, vagy a vallási képviselet tagjaként megfordultak a törvényhatósági bizottságban.

A város polgármestere, Koller Jenő a lehetỏ leghumánusabb megoldást terjesztette a miniszterelnök elé. A fővárosi minta alapján három házcsoportot alakított ki. Eszerint lettek volna tiszta zsidó, tiszta keresztény, illetve vegyes utcák. Az első tervet megvizsgálva láthatjuk, az ún. zsidó utcákon, illetve tereken (a Bisinger sétány, a Batthyány tér, a Deák, a Kisfaludy, a Király, a Dunaszer, a Czuczor, illetve a dr. Kovács Pál utcák) már eleve sok zsidó tulajdonú ház, illetve lakás volt található, valamint ezek az épületek nagy alapterületủek voltak és folyóvízzel, fürdőszobával való ellátottságuk is nagyon jó volt. A lehetö legkevesebb embernek kellett volna költöznie, a családok segíthették volna egymást, illetve a higiéniás körülmények is jók voltak. Már megkezdődött a költözködés, de Jaross Andor belügyminiszter nem értett egyet ezzel a megoldással, mondván, a győri zsidó lakosságot egy jól ellenörizhető és elzárható területre kell telepíteni. A gettó új helyét 1944. május 15-én jelölték ki, ami a Mosoni Duna, a Rábca és a Bercsényi liget határolta területen helyezkedett el. Mondani sem kell, hogy a belügyminiszter részéről ez egy kifejezetten embertelen megoldás volt. A győri zsidó és nem zsidó lakosság lakóhelyei az 1870-es évektől fokozatosan keveredtek. Az egykori zsidó városrészről a tehetösebb polgárok beköltöztek a város központi részeibe. 1904-től Sziget és Győr egyesítésével pedig ez a folyamat még inkább felgyorsult. Az üresen maradt, alacsony komfort fokozatú kisebb házakat, lakásokat a keresztény polgárok vásárolták meg. Itt is volt tehát alapos keveredés és elzárni sem lehetett. Viszont a körülmények sokkal rosszabbak voltak. A házak kicsik, a tér szük és a higiéniás feltételek is igen rosszak voltak. A belügyminiszternek még ez sem tetszett. A város még próbálta halasztani a harmadik és teljesen borzalmasnak nevezhető gettóba való áttelepítést, de a győri elit ekkor már teljesen tehetetlen volt. Az új helyszín a Buda utcai barakk volt, ami az I. világháborúban épült. Katonai szükségkórháznak épült, és 1944-re 
szinte lakhatatlanná vált az állapota. Ki gondolta volna,hogy ez a romhalmaz még ezreknek lesz hajléka, még ha csak rövid időre is. Méltatlan volt ez nemcsak az emberekhez,hanem ahhoz a kapcsolathoz is, ami 1848 után a város különböző vallási csoportjai között kialakult. A nagy történelmi erötér azonban felülírta az ország sorsát és benne a települések életét is.

\section{Befejezés}

Győr történelmében 1870 és 1945 között egy bỏ emberöltő telt el. A kollektív nemzeti emlékezet ezeket az éveket a „boldog békeidő”, illetve a „vészkorszak” jelzőjével tartja számon. Értékekben, mentalitásokban és emberi sorsokban össze nem vethetổ időszakok szabtak új irányt a település életének. Mégis mi a közös ebben a szinte összekapcsolhatatlan történeti folyamatban? Ez pedig nem más, mint a családi és nemritkán az egyéni életek folytonossága, ami összekapcsolja a legkülönfélébb politikai időszakokat. Azon győri polgárok közül, akik az 1870-es évektől új és sikeres fejlődési pályára állították a várost, sokan még megérték a II. világháborút és az 1944-es évet. A györi siker abban gyökerezett, hogy a városi elit befogadó jellegủ volt, a változást nemcsak elfogadta, hanem maga is kezdeményezte, és ami a legfontosabb, alapvetően egységes volt. A külső politikai erötér azonban 1944-ben ezt a generációs magatartásmódot alapjaiban változtatta meg. A virilizmus intézményén keresztül a különbözö vallási csoportok, közöttük igen jelentős arányban a település zsidó polgárai évtizedeken át együtt vettek részt a város politikai vezetésében. Ezen kívül gazdag üzleti és magánéleti kapcsolatok szövődtek. Igaz, hogy felső és igen erőteljes nyomásra most jó ismerösöknek, esetleg barátoknak kellett végrehajtani ezeket a borzalmas rendelkezéseket. A régi értékrendszer még müködött. Igyekeztek elviselhetövé tenni az állapotokat, de ehhez már gyengék voltak.

Sajnos a korábban és hosszú idő alatt kiformálódott értékrendszer és magatartásmód nem tudott generációk során áthagyományozódni, hiszen az ország és a település élete az 1940-es évektől többször is törést szenvedett, és a múlt folytatása mellett annak megtagadása vált a vezérlỏ elvvé.

\section{Jegyzetek}

\footnotetext{
${ }^{1}$ Ezeket a gondolatokat részletesebben ld. Szakál (2002).

${ }^{2}$ Az I. világhábonút követỏ traumatikus változások során a határszéli nagyvárosok közül talán Győrt érte a legkisebb veszteség. (Erre külön vizsgálatok nincsenek.)

${ }^{3}$ A leggazdagabb győri polgárok - az adólisták szerint -, vagy éppen a korabeli közvélekedés szerinti vállalkozók négy évtized alatt némileg változó bó tucatnyi csoportjában a zsidó származásúaknak csak szolid megjelenését tapasztaltuk. Ugyanez vonatkozik a város vezetỏ kereskedelmi utcájára, a Baross útra is: a zsidó üzletek csak nehezen és szolid megjelenéssel tudtak bekerülni ebbe az exluzív térbe.

${ }^{4}$ A két világháború közötti éveket és a vészkorszak eseményeit ez idáig ebböl a szempontból csak Lónyai Sándor tekintette át röviden. Az események részletes ismerete még sok kutatást igényel.
} 
${ }^{5}$ Györ Megyei Város Levéltára X/1. A Baross Szövetség győri csoportjának az iratai 1937-1944. Az iratanyag még teljesen feldolgozatlan.

\title{
Irodalom
}

Assmann, J. (1999) A kulturális emlékezet. Irás, emlékezés és politikai identitás a korai magas kultúrákban. Atlantisz, Budapest.

Augustine, D.L. (2001) Beérkezés a felsőosztályba - A vilmosi Németország vagyonos üzleti elitje. Mühely. 2.68-80. o.

Balázs P. (1980) Györ a feudalizmus bomlása és a polgári forradalom idején. Akadémiai Kiadó, Budapest. Györ gyárváros. (1896) - Györi Hírlap. 68. 1. o.

Győri Hírlap. (1896) 17. 1. o.

Koselleck, R. (1979) Vergangene Zukunft. Zur Semantik geshichtlicher Zeiten. Suhrkamp Verlag, Frankfurt am Main.

Körner A. (2005) Kóstoló a múltból. Egy XIX. századi magyar zsidó háziasszony mindennapjai és konyhája. Vince Kiadó, Budapest.

Lónyai S. (2004) A Numerus Clausustól Auswitzig. Labor Press, Budapest.

A munka és a tudomány. (1857) - Új Képes Györi Czím és Ügynaptár 1857. évre. Györ. 37. o.

Neveljünk iparosokat - A polgármester elöterjesztéséhez. (1896) - Györi Hírlap. 9. 1-2. o.

Quittner, E. (1996) Az emlékezés kavicsai. Magánkiadás, Győr.

Pilbeam, P. (2001) Kik voltak a középosztálybeliek? - Mühely. 2. 61-67. o.

Stádel K. (1879) Kereslet és szükséglet. - Nagy-Györi Naptâr az 1879-es közönséges évre. Györ. 57. o.

Szakál Gy. (2002) Vállalkozó gyốri polgárok. L'Harmattan, Budapest.

A társadalom elégületlenei - Levél a szerkesztóhöz. (1896)-Györi Hírlap. 57. 2. o.

\section{THE SCALE OF VALUE AND BEHAVIUR OF THE ELITE IN GYÓR DURING THE ECONOMIC AND POLITICAL CRISIS BETWEEN 1870 AND 1945}

\author{
GYULA SZAKÁL
}

Communities can be valued upon what type of elite they create. The way elite groups are being created or the way they come to live is very much connected to the historical ambience in which they nurture. The elite in Györ exemplifies this paradigm in the time lapse between the two World Wars. Although the town had a geographically excellent position it was rather the economic, political and cultural elite that determined the faith and prosperity of the community. The cohesion of the three elite groups were much stronger till up to the Ind World War, than they are at present. The cultural phenomenon, like the hospitality, the urban lifestyle and value system, the opportunities provided by the council, the social responsibility of the elite, the feeling of solidarity all played a crucial role in handling both the economic and political crises. As from the beginning of the XIXth century till the end of the IInd World War the elite groups of Gyór derived from the same network of families, the responses to challenges proved to be consequential and stable. The change from a merchant town to an industrialised one, just as the crises of the World Wars were managed by the same elite, which was hospitable enough for instance to integrate Jewish communities throughout several generations. In the era of the holocaust the Christian members of the town's elite groups did all they could to support or aid this Jewish community. 